\title{
The Sox9 transcription factor determines glial fate choice in the developing spinal cord
}

\author{
C. Claus Stolt, ${ }^{1}$ Petra Lommes, ${ }^{1}$ Elisabeth Sock, ${ }^{1}$ Marie-Christine Chaboissier, ${ }^{2}$ Andreas Schedl, ${ }^{2}$ \\ and Michael Wegner ${ }^{1,3}$ \\ ${ }^{1}$ Institut für Biochemie, Universität Erlangen-Nürnberg, 91054 Erlangen, Germany; ${ }^{2}$ INSERM U470, Institute de Biochimie, \\ Université Nice, 06108 Nice cedex 2, France
}

\begin{abstract}
The mechanism that causes neural stem cells in the central nervous system to switch from neurogenesis to gliogenesis is poorly understood. Here we analyzed spinal cord development of mice in which the transcription factor Sox9 was specifically ablated from neural stem cells by the CRE/loxP recombination system. These mice exhibit defects in the specification of oligodendrocytes and astrocytes, the two main types of glial cells in the central nervous system. Accompanying an early dramatic reduction in progenitors of the myelin-forming oligodendrocytes, there was a transient increase in motoneurons. Oligodendrocyte progenitor numbers recovered at later stages of development, probably owing to compensatory actions of the related Sox10 and Sox8, both of which overlap with Sox9 in the oligodendrocyte lineage. In agreement, compound loss of Sox9 and Sox10 led to a further decrease in oligodendrocyte progenitors. Astrocyte numbers were also severely reduced in the absence of Sox9 and did not recover at later stages of spinal cord development. Taking the common origin of motoneurons and oligodendrocytes as well as V2 interneurons and some astrocytes into account, stem cells apparently fail to switch from neurogenesis to gliogenesis in at least two domains of the ventricular zone, indicating that Sox9 is a major molecular component of the neuron-glia switch in the developing spinal cord.
\end{abstract}

[Keywords: HMG-box; Sry; Sox10; neural stem cell; oligodendrocyte; astrocyte]

Received January 8, 2003; revised version accepted May 5, 2003.

Neuronal specification has been intensely studied in the spinal cord (for review, see Jessell 2000). Neuronal subtypes are generated in response to a Sonic hedgehog gradient that emanates from notochord and floorplate, and influences the expression of transcription factors along the dorsoventral axis. Some of these transcription factors are repressed (class I) by Sonic hedgehog, and others are induced (class II). Because of the cross-repressive action of these transcription factors, domains are established in the ventricular zone along the dorsoventral axis, with each domain defined by expression of a certain set of transcription factors and giving rise to a particular type of neuron. Thus, motoneurons arise from the pMN domain in the ventral part of the ventricular zone, whereas V2 interneurons are generated from the dorsally abutting p2 domain.

Although neuronal specification and its underlying molecular principles are well understood, relatively little is known about the origin of glia in the spinal cord

${ }^{3}$ Corresponding author.

E-MAIL m.wegner@biochem.uni-erlangen.de; FAX 4991318522484. Article and publication are at http://www.genesdev.org/cgi/doi/10.1101/ $\operatorname{gad} .259003$. (for review, see Kessaris et al. 2001). Stem cells within the ventricular zone cease to produce neurons at around midgestation and instead start to produce glia. What causes these stem cells to switch from neurogenesis to gliogenesis is unknown at present.

Myelin-forming oligodendrocytes and nonmyelinating astrocytes are the two main types of glia in the central nervous system (CNS). They appear to arise from different regions of the ventricular zone, with oligodendrocytes being derived from the same pMN domain that gave rise to motoneurons before. Generation of both motoneurons and oligodendrocytes is dependent on the action of the Olig1/2 transcription factors of the bHLH family (Lu et al. 2002; Takebayashi et al. 2002; Zhou and Anderson 2002). The origin of astrocytes within the ventricular zone is less well defined. Recent studies have shown, however, that the $\mathrm{p} 2$ domain is capable of astrocyte production (Zhou and Anderson 2002; Pringle et al. 2003). Additionally, astrocytes appear to be generated by transdifferentiation of radial glia (Bignami and Dahl 1974; Malatesta et al. 2003), pointing to a heterogeneous origin of astrocytes.

We have shown that glial cells of the CNS express proteins of the Sox family of transcription factors (Kuhl- 
brodt et al. 1998a,b; Sock et al. 2001). Sox proteins in general are characterized by possession of a variant highmobility-group domain that allows sequence-specific minor-groove DNA binding and concomitant DNA bending. Sox proteins can be grouped into seven major classes and have important roles during development (Wegner 1999; Bowles et al. 2000). The class E protein Sox10, for instance, is essential for development of several neural-crest-derived cell types, including all peripheral glia (Herbarth et al. 1998; Southard-Smith et al. 1998; Britsch et al. 2001). In the CNS, Sox10 occurs selectively in oligodendrocytes and is essential for the terminal differentiation of these cells (Stolt et al. 2002). Sox10 expression in the oligodendrocyte lineage significantly precedes the onset of terminal differentiation, but is apparently not essential during these earlier times.

In addition to Sox10, oligodendrocytes also express the related Sox 8 protein (Sock et al. 2001). Coexpression of Sox 8 and Sox10 is observed both in developing and terminally differentiated oligodendrocytes with little changes in the relative levels of both transcription factors during lineage progression. This and normal oligodendrocyte development in Sox8-deficient mice (Sock et al. 2001; C.C. Stolt and M. Wegner, unpubl.) make it unlikely that functional compensation by Sox 8 is the main reason for the absence of an early oligodendrocyte defect in Sox10-deficient mice.

The second protein closely related to Sox10 is Sox9, which is best known for its role during chondrocyte development and male sex determination (Wright et al. 1995; Kent et al. 1996; Bi et al. 1999). Heterozygous mutations in humans lead to campomelic dysplasia (MIM 114290), a skeletal malformation syndrome frequently associated in males with XY sex reversal (Foster et al. 1994; Wagner et al. 1994). Poorly characterized defects in the CNS are, however, additionally observed in campomelic dysplasia patients, indicating that there might be an additional role of Sox 9 in the CNS.

Here, we show that Sox 9 is strongly expressed first in neural stem cells, and later in glial cells of the CNS, and that it is essential for proper development of both oligodendrocytes and astrocytes. Not only do our findings explain the previously noted absence of an early oligodendrocyte defect in Sox10-deficient mice, it also defines Sox 9 as a component of the mechanism that causes neural stem cells to switch from neurogenesis to gliogenesis.

\section{Results}

\section{Sox9 expression during spinal cord development}

Sox 9 expression in the developing mouse spinal cord was analyzed both by immunohistochemistry and in situ hybridization with similar results (Fig. 1; data not shown). At 8.5 days postcoitum (dpc), Sox9 was detectable in the emerging neural crest at the dorsal aspect of the neural tube (Fig. 1a) in agreement with previous studies on Xenopus embryos (Spokony et al. 2002). At 9.5 dpc, Sox 9 became weakly visible in cells of the ventral neural tube (Fig. 1b). By 10.5 dpc, Sox9 was expressed throughout the ventricular zone (Fig. 1c), with expression levels increasing over the next $24 \mathrm{~h}$ (Fig. 1d). From $12.5 \mathrm{dpc}$ onward, Sox 9 expression was not only detected in the ventricular zone, but also in single cells migrating out at various levels along the dorsoventral axis (Fig. 1e). Over the following days, the number of Sox9-positive cells in the ventricular zone decreased steadily, paralleling the reduction of ventricular zone and neuroepithelial cells (Fig. 1f-h). At the same time, Sox9-expressing cells in the surrounding parenchyma increased dramatically. The relatively late appearance of these cells, the shape of their nuclei, and their scattered distribution pointed to a glial identity.

Coimmunohistochemistry was performed to determine the Sox9-expressing cell types exactly. Within the ventricular zone, all cells exhibited nuclear Sox9 staining, the nestin-positive neuroepithelial stem cells as well as the brain fatty acid binding protein (B-FABP)- and



Figure 1. Sox 9 expression pattern in the embryonic spinal cord. Immunohistochemistry was performed on transverse sections from the forelimb region of wild-type embryos with an antibody specifically directed against Sox9. (a) 8.5 dpc. (b) 9.5 dpc. (c) 10.5 dpc. (d) 11.5 dpc. (e) 12.5 dpc. (f) 14.5 dpc. (g) 16.5 dpc. (h) 18.5 dpc. 
nestin-positive radial glia (data not shown). Sox9 remained present in radial glia throughout embryogenesis (Fig. 2a), and in radial glia of the adult CNS such as the cerebellar Bergmann glia (Pompolo and Harley 2001). In the late embryonic and adult spinal cord, all glial fibrillary acidic protein (GFAP)-positive cells strongly expressed Sox9, identifying astrocytes as the second Sox9containing cell type (Fig. 2b,c). A fraction of Sox9-expressing cells in the embryonic spinal cord was also positive for markers of oligodendrocyte progenitors, including PDGF receptor $\alpha$ (Fig. 2d). In contrast to this widespread expression in glia, Sox 9 was not found in cells labeled by neuronal markers, including the panneuronal marker NeuN and markers for various neuronal subtypes (Fig. 2e; see below). In addition to neurons, endothelial cells in the developing spinal cord were also Sox9-negative as evident from anti-Sox9 coimmunohistochemistry with antibodies directed against PECAM-1 or Flk-1 (Fig. 2f,g).

Sox9 expression in oligodendrocytes was studied in closer detail by comparison with $\beta$-galactosidase previously inserted into the Sox 10 locus ( $\beta$-galactosidase ${ }^{\text {Sox 10; }}$; see Britsch et al. 2001). This marker faithfully recapitulates Sox10 expression through all stages of oligodendrocyte development (Stolt et al. 2002). When oligodendrocyte progenitors appeared at $12.5 \mathrm{dpc}$ at the border of the ventricular zone in the pMN domain of the ventral spinal cord, they were already positive for Sox9 (Fig. 2i). Sox9 expression was maintained in migrating, actively proliferating oligodendrocyte progenitors throughout the parenchyma at $14.5 \mathrm{dpc}$ and at later stages (Fig. 2j; data not shown). Upon accumulation of oligodendrocyte progenitors during late embryogenesis in the marginal zone, Sox 9 expression became heterogeneous with strong expression in some oligodendrocytes, and residual or no Sox9 staining in others (Fig. 2k). These changes coincided with the onset of terminal differentiation and were indicative of a down-regulation of Sox9 in differentiating, myelin-forming oligodendrocytes. Accordingly, Sox9 was undetectable in oligodendrocytes that had started to express MBP or other terminal differentiation markers (Fig. 2h; data not shown). In the white matter of adult spinal cord, Sox9 was furthermore excluded from oligodendrocytes and restricted to astrocytes (Fig. 2c,1). Hallmarks of Sox9 expression, that is, continued presence in astrocytes, transient occurrence in oligodendrocytes, and absence in neurons, were also confirmed for other parts of the CNS (data not shown).

\section{Sox9 ablation in the developing spinal cord}

To study the role of Sox 9 in the developing mouse spinal cord by loss-of-function experiments, Sox 9 had to be ablated in a tissue-specific manner, as heterozygous loss of Sox9 is already lethal in mice (Bi et al. 2001). We have done this using the Cre/lox $P$ recombination system. Mice with a floxed Sox9 allele (Sox $9^{\text {loxP }}$; see Akiyama et al. 2002) were crossed with mice carrying a Cre transgene under the control of the rat nestin promoter and enhancer (NesCre; see Tronche et al. 1999). Cre expression in neuroepithelial cells throughout the ventricular zone ablates Sox9 $\left(\mathrm{Sox}^{4}\right)$ in these cells and their neuro-

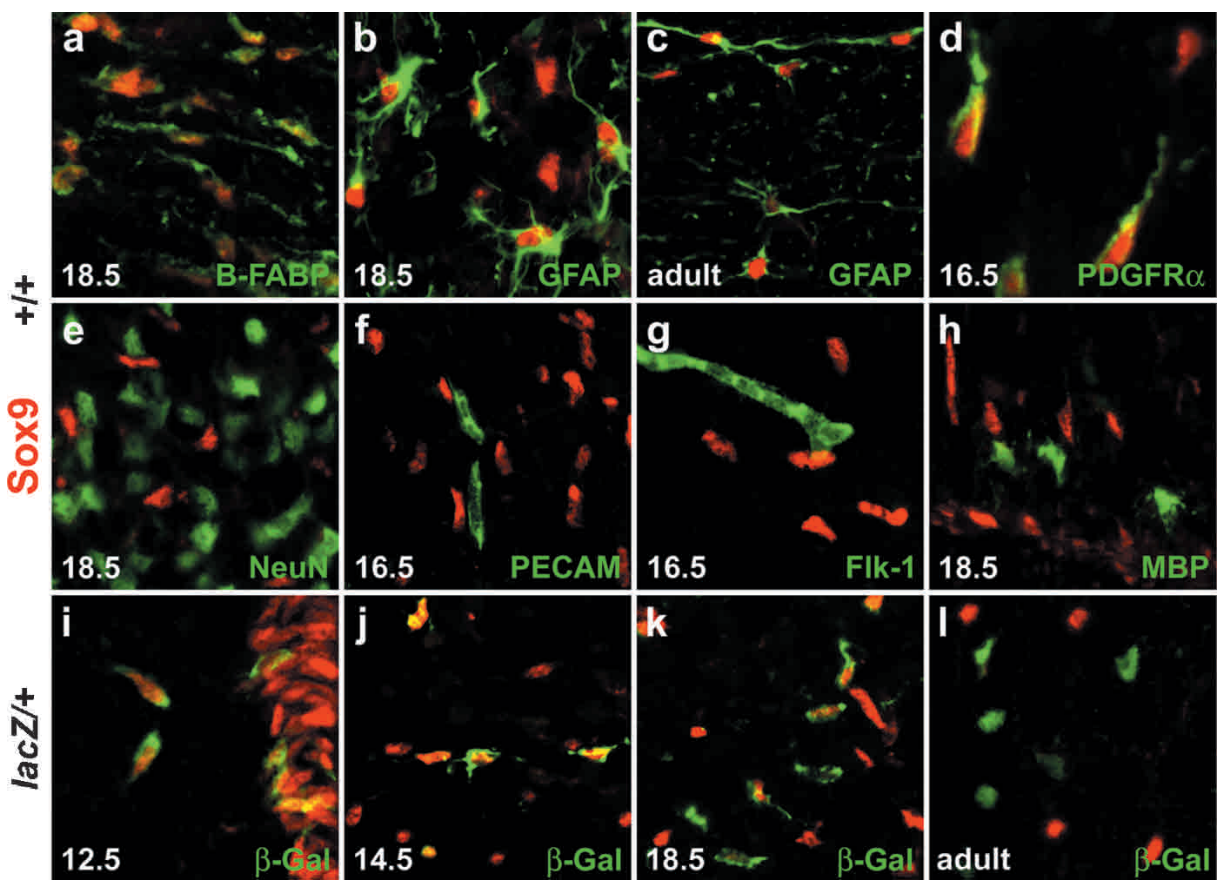

Figure 2. Sox9-expressing cell types in the central nervous system. Immunohistological analysis of embryonic and adult spinal cord (stages as mentioned in the panels) of wild-type $(+/+; a-h)$ and Sox10 lacZ/+ $($ lacZ/+; $i-1)$ mice using antibodies against Sox9 (red) in combination with various cell-type specific antibodies (green), including B-FABP $(a)$, GFAP $(b, c)$, PDGF receptor $\alpha(d)$, NeuN $(e)$, PECAM-1 $(f)$, Flk-1 $(g), \operatorname{MBP}(h)$, and $\beta$-galactosidase ${ }^{\text {Sox10 }}(i-1)$. 
nal and glial derivatives. At $10.5 \mathrm{dpc}$, spinal cord stem cells in the forelimb area were actively undergoing Sox9 ablation with different kinetics in the dorsal and ventral parts. Residual Sox9 expression was detected in many cells of the dorsal ventricular zone and in a few scattered cells at more ventral positions, including the pMN domain (cf. Figs. 3a and 1c). Efficient ablation throughout the spinal cord was achieved in the forelimb area from $12.5 \mathrm{dpc}$ onward (cf. Figs. 3b-d and 1e-g; data not shown), at which time the ventricular zone switches from neurogenesis to gliogenesis (Kessaris et al. 2001). Outside the CNS, Sox9 staining appeared normal, as indicated by expression in mesenchymal chondrocytic condensations, lung, kidney, and gonads (e.g., Fig. $3 \mathrm{a}-\mathrm{d}$; data not shown).

Mice with Sox9 ablation in the central nervous system died perinatally. Until $14.5 \mathrm{dpc}$, CNS development appeared normal by morphological criteria. At $16.5 \mathrm{dpc}$ and $17.5 \mathrm{dpc}$, variable size reductions were observed for the spinal cord, although the rate of apoptosis as determined by TUNEL assays was similar to the wild type (Fig. 3e,h,k for 16.5 dpc; Fig. 3f,i,k for 17.5 dpc). Only $1 \mathrm{~d}$ later at $18.5 \mathrm{dpc}$, apoptotic figures were dramatically increased and spinal cord tissue was undergoing generalized degeneration (Fig. 3g, j, k). Severe hemorrhage at this age pointed to a loss of vascular integrity. From immunofluorescence studies with cell-type-specific markers, neurons appeared more severely affected than glial cells (data not shown). The underlying cause of spinal cord degeneration is unknown, but might be associated to earlier developmental defects intrinsic to the CNS. For the description of these defects, we focused on the forelimb area of the spinal cord. Qualitatively similar phenotypes have also been observed at other axial levels.

Despite the early loss of Sox9, no changes were observed in the ventricular zone with regard to overall appearance, width, and expression of marker genes such as the pan-ventricular zone marker nestin and the domain markers Olig2, Nkx2.2, Nkx6.1, and Irx3 (Fig. 4a-j; data not shown). In particular, the expression domains for Olig2, Nkx2.2, Nkx6.1, and Irx3 maintained their position relative to each other (Fig. 4a-j), indicating that at least the three ventralmost domains of the ventricular zone (Jessell 2000) kept their identity and position along the dorsoventral axis. Additionally, we were unable to detect significant alterations in apoptosis or proliferation throughout the ventricular zone (data not shown). B-FABP-positive cells appeared on time and persisted throughout embryogenesis, indicating that the usually Sox9-expressing radial glia developed normally in the absence of this transcription factor (Fig. 4k-p). In agreement with the absence of Sox 9 in neurons, we did not observe any gross alteration in overall localization and differentiation of neurons using the pan-neuronal marker NeuN (data not shown).

\section{Oligodendrocyte development in the Sox9-deficient spinal cord}

Oligodendrocytes arise in the pMN domain of the ventral ventricular zone after this domain has ceased to produce motoneurons (Kessaris et al. 2001). Neuroepithelial precursors within the pMN domain of the ventricular zone are positive for Olig2, as are the oligodendrocyte
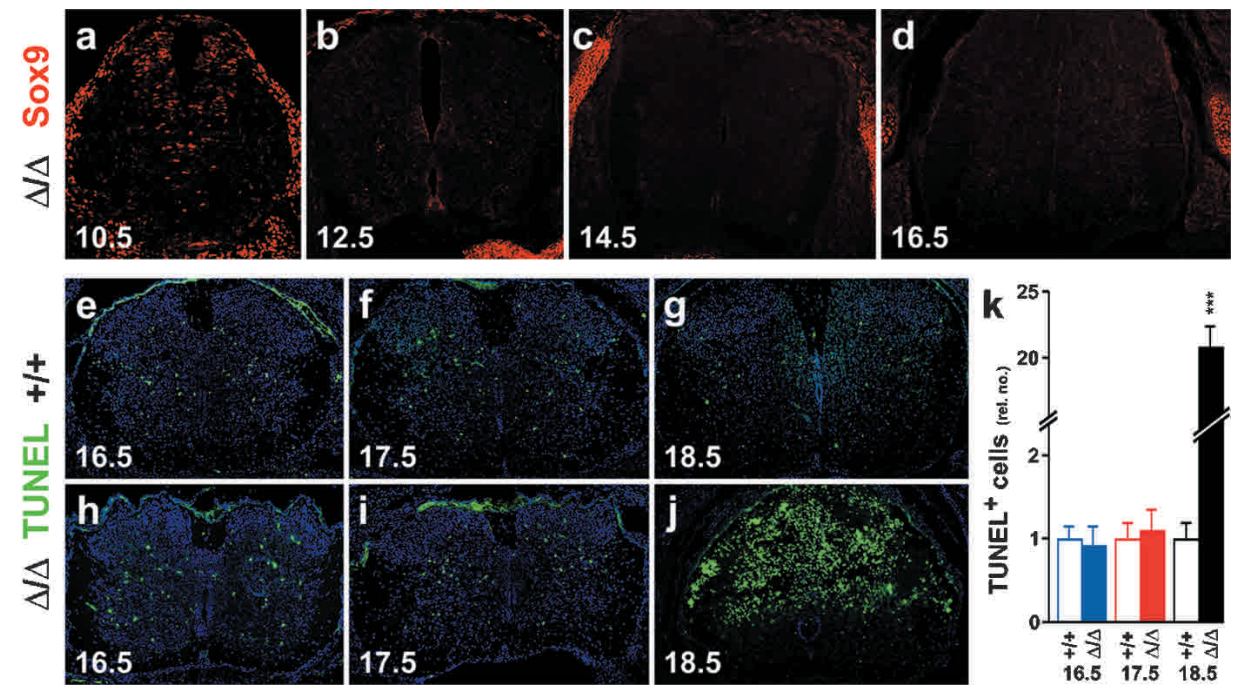

Figure 3. Ablation efficiency and development in Sox9-deficient spinal cords. $(a-d)$ Immunohistochemistry with a Sox9-specific antibody on transverse sections from the forelimb region of Sox $9^{\Delta / \Delta}$ embryos. $(a) 10.5$ dpc. (b) 12.5 dpc. (c) 14.5 dpc. (d) 16.5 dpc. Note normal Sox 9 expression in mesenchymal condensations. (e-j) TUNEL labeling of transverse sections from the forelimb region of wild-type $(+/+; e-g)$ and Sox $9^{\Delta / \Delta}(h-j)$ spinal cords at $16.5 \mathrm{dpc}(e, h), 17.5 \mathrm{dpc}(f, i)$, and $18.5 \mathrm{dpc}(g, j)$. Tissues were counterstained with DAPI (blue). ( $k$ ) Quantification of TUNEL labeling in wild-type (open bars) and Sox9-deficient (filled bars) spinal cords at 16.5, 17.5, and $18.5 \mathrm{dpc}$. The number of TUNEL-positive cells obtained for the wild type was arbitrarily set to 1 . All other values were expressed relative to wild-type levels and are presented as mean \pm S.E.M. (for method, see Figs. 5,7,9). Statistical significance was determined by the Student's t test and is indicated above the respective bars (three asterisks for $P \leq 0.001$ ). 

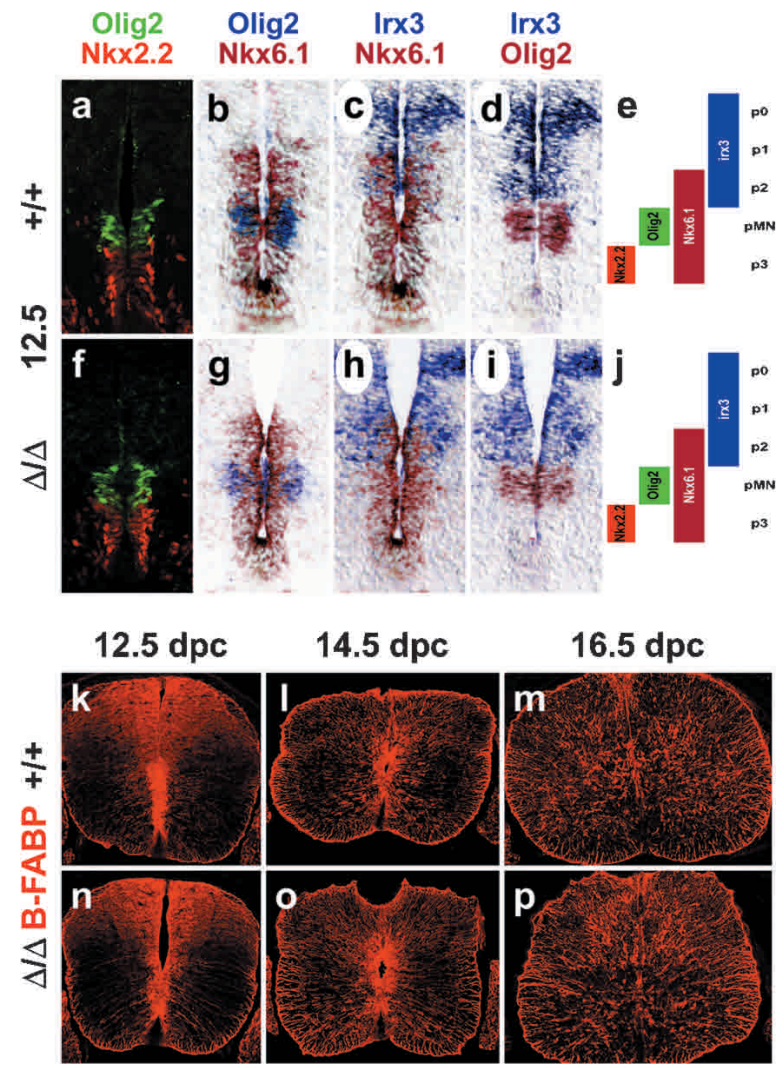

Figure 4. Stem cell and radial glia development in embryonic Sox9-deficient spinal cords. (a-j) Immunohistochemistry with antibodies specific for Nkx2.2 and Olig2 $(a, f)$ and in situ hybridizations with antisense probes specific for Olig2, Nkx6.1, and Irx3 $(b-d, g-i)$ were performed on transverse sections from the forelimb region of embryos at $12.5 \mathrm{dpc}$ to determine the integrity of the three ventral stem cell domains of the ventricular zone (p2, pMN, p3) as summarized in $e$ and $j$. In situ hybridization signals obtained with different probes on immediately adjacent sections were superimposed using Adobe Photoshop with the color of one of the signals being converted to red. $(k-p)$ Immunohistochemistry with antibodies specific for the radial glia marker B-FABP were performed on transverse sections from the forelimb region of embryos. $(a-e, k-m)$ Wild-type $(+/+)$ spinal cords. $(f-i, n-p)$ Sox $9^{\Delta / \Delta}$ spinal cords. $(a-k, n) 12.5$ dpc. $(1, o) 14.5$ dpc. $(m, p) 16.5$ dpc.

progenitors derived from them (Lu et al. 2002; Takebayashi et al. 2002; Zhou and Anderson 2002). When Sox9deficient and wild-type spinal cords were compared at $12.5 \mathrm{dpc}$ by immunohistochemistry, Olig2 signals in the ventricular zone appeared highly similar, indicating intactness of the common motoneuron/oligodendrocyte precursors (Fig. 5a,d; VZ in Fig. 5o). Olig2 expression in migrating oligodendrocyte progenitors outside the ventricular zone was sparse at this age in the wild type and almost completely missing in Sox9-deficient spinal cords (Fig. 5a,d; MZ in Fig. 5o), pointing to a possible defect in oligodendrocyte specification. At this age, Olig2 cannot reliably distinguish neuroepithelial cells and freshly specified oligodendrocyte progenitors at the border of the ventricular zone. Sox10, in contrast, is se-



Figure 5. Oligodendrocyte development in embryonic Sox9deficient and Sox9/Sox10-deficient spinal cords. Immunohistochemistry with antibodies specific for the pMN stem cell and oligodendrocyte marker Olig2 $(a-f)$, and the oligodendrocyte markers Sox10 $(g-l)$ and $\beta$-galactosidase ${ }^{\text {Sox10 }}(m, n)$ were performed on transverse sections from the forelimb region of embryos. $(a-c, g-i)$ Wild-type spinal cords. $(d-f, j-l)$ Sox $9^{\Delta / \Delta}$ spinal cords. $(m, n)$ Sox $9^{\Delta / \Delta}$, Sox $10^{\text {lacZ/lacZ }}$ spinal cords. $(a, d, g, j, m) 12.5$ dpc. $(b, e, h, k, n) 14.5$ dpc. $(c, f, i, l) 16.5$ dpc. $(o, p)$ Quantification of oligodendrocytic cells in wild-type $(+/+$; open bars), Sox9-deficient $(\Delta / \Delta$; filled bars $)$, and Sox9/Sox10-deficient $(\Delta / \Delta,-/-$; filled bars) spinal cords, as indicated below the bars. The number of Olig2-positive cells $(o)$ or Sox10/ $\beta$-galactosidase ${ }^{\text {Sox10 }}$-positive cells $(p)$ was determined at $12.5 \mathrm{dpc}, 14.5 \mathrm{dpc}$, and $16.5 \mathrm{dpc}$ as indicated. For $12.5 \mathrm{dpc}$, Olig2-positive cells within (VZ) and outside (MZ) the ventricular zone were separately quantified. At least 15 separate 10 - $\mu \mathrm{m}$ sections from the forelimb region of $\geq 2$ independent embryos were counted for each genotype. The number of cells obtained for the wild type was arbitrarily set to $100 \%$. All other values were expressed relative to wild-type levels and are presented as mean \pm S.E.M. Statistical significance was determined by the Student's t test and is indicated above the respective bars (three asterisks for $P \leq 0.001$ ). 
lectively expressed in oligodendrocytes immediately after specification (Lu et al. 2002; Stolt et al. 2002; Zhou and Anderson 2002). Approximately half the cells labeled by Olig2 also expressed Sox10 in the wild type (Fig. $5 \mathrm{a}, \mathrm{g})$, thus identifying on average 42 cells per section as oligodendrocyte progenitors. In Sox9-deficient spinal cords, however, only two cells per section were found on average to be positive for Sox10 (Fig. 5j,p). This corresponds to a $95 \%$ reduction of oligodendrocyte numbers and thus corroborates a severe defect in oligodendrocyte specification.

At $14.5 \mathrm{dpc}$, Olig2- and Sox10-expressing oligodendrocyte progenitors have dispersed throughout the spinal cord parenchyma in the wild type (Fig. 5b,h). In the absence of Sox9, migrating oligodendrocyte progenitors were strongly reduced as judged by both markers (Fig. $5 \mathrm{e}, \mathrm{k})$. Quantitative analysis of Olig2 and Sox10 expression revealed that the number of oligodendrocyte progenitors in Sox9-deficient spinal cords at $14.5 \mathrm{dpc}$ is only $22 \%-25 \%$ of that seen in age-matched wild-type spinal cords (Fig. 5o,p). In general, oligodendrocyte progenitors in Sox9-deficient spinal cords were more medially and ventrally restricted than in the wild type, indicating a delay in oligodendrocyte development. Corroborating this delay, expression of the NG2 proteoglycan (Liu et al. 2002) was significantly retarded in oligodendrocyte progenitors both at $14.5 \mathrm{dpc}$ and $16.5 \mathrm{dpc}$ (green signal in Fig. 6a-d). In contrast, no difference was observed for NG2 expressed in endothelial cells of the spinal cord, identified by PECAM-1 colabeling (yellow signal in Fig. 6a-d). Oligodendrocyte numbers were still reduced at $16.5 \mathrm{dpc}$, but had recovered to $73 \%$ of wild-type levels (Fig. $5 \mathrm{c}, \mathrm{f}, \mathrm{i}, \mathrm{l}, \mathrm{o}, \mathrm{p}$ ). We assume that elevated proliferation rates account for the normalization of oligodendrocyte numbers during development, because the percentage of actively proliferating oligodendrocyte progenitors positive for both PCNA and Olig2 was higher in the Sox9deficient spinal cord than in the age-matched wild type $(86 \% \pm 8 \%$ vs. $72 \% \pm 8 \%$ at $16.5 \mathrm{dpc}$ ).

Late ablation of Sox9 in a minor fraction of stem cells in the ventral part of the ventricular zone, including the pMN domain (Fig. 3a), might be responsible for the initial appearance of a few oligodendrocyte progenitors. These cells could give rise to all oligodendrocyte progenitors detected at later stages, if cell divisions are initially in the range of $12 \mathrm{~h}$. Alternatively, the requirement for Sox9 during oligodendrocyte specification in the pMN domain may not be absolute. Thirdly, oligodendrocyte progenitors might be recruited from other domains of the ventricular zone, such as the p3 domain, which has recently been implicated as an alternate source of oligodendrocytes (Zhou et al. 2001; Fu et al. 2002). These oligodendrocyte progenitors are believed to first express the transcription factor $\mathrm{Nkx} 2.2$, migrate into mantle and marginal zones, and only then turn on other oligodendrocyte markers such as Olig2. We did not detect a relative increase of Nkx2.2-positive cells among the Olig2positive oligodendrocyte progenitors in Sox9-deficient spinal cords at either $14.5 \mathrm{dpc}$ or $16.5 \mathrm{dpc}$ (Fig. 6e,f; data not shown), thus discounting a model in which pMN-
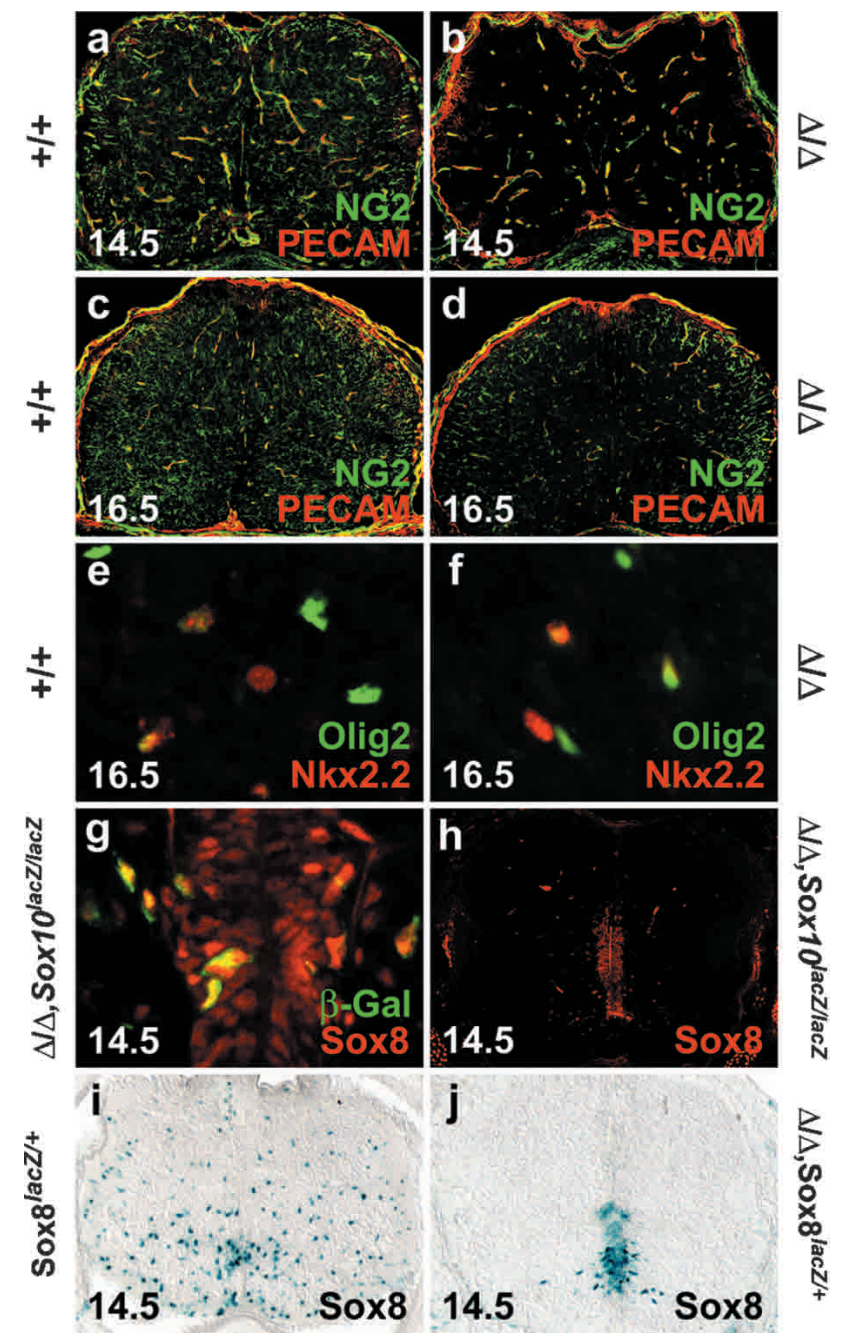

R

Figure 6. Marker gene expression in Sox9-deficient and Sox9/ Sox10-deficient spinal cords. $(a-d)$ Immunohistochemistry with antibodies specific for NG2 (green) and PECAM-1 (red) were performed on transverse sections of wild-type $(a, c)$ and Sox $9^{\Delta / \Delta}$ $(b, d)$ spinal cords from the forelimb region of embryos at 14.5 dpc $(a, b)$ and $16.5 \mathrm{dpc}(c, d)$. The green signal is specific for oligodendrocytes, whereas the yellow color indicates colocalization of NG2 and PECAM-1 in blood vessels (see also Liu et al. 2002). (e,f) Immunohistochemical analysis with antibodies directed against $\mathrm{Nkx} 2.2$ (red) and Olig2 (green) on wild-type (e) and $\operatorname{Sox}^{\Delta / \Delta}(f)$ spinal cords at $16.5 \mathrm{dpc}$. $(g, h)$ Immunohistochemistry with antibodies directed against Sox class E proteins (red) on Sox $9^{\Delta / \Delta}$, Sox $10^{\text {lacz/lacz }}$ spinal cords at $14.5 \mathrm{dpc}$, in combination with antibodies against $\beta$-galactosidase ${ }^{\text {Sox10 }}$ ( $g$; green) or alone $(h) .(i, j)$ Comparison of Sox8 expression in Sox $8^{+/ \text {lacZ }}(i)$ and $\operatorname{Sox} 9^{\Delta / \Delta}$, Sox $8^{+/ \text {lacZ }}(j)$ spinal cords at $14.5 \mathrm{dpc}$ by X-gal staining for $\beta$-galactosidase ${ }^{\text {Sox } 8}$.

derived oligodendrocytes are replaced by p3-derived ones.

By $12.5 \mathrm{dpc}$, Cre recombinase had completely ablated Sox9 in oligodendrocyte progenitors and in neuroepithelial cells of the pMN domain of most embryos. Thus once specified, oligodendrocyte progenitors were no longer dependent on Sox9 despite the fact that these cells 
still express Sox9 under normal conditions. Taking into account that Sox9 expression in oligodendrocyte progenitors is closely followed by expression of Sox10 and Sox8 (Sock et al. 2001; Stolt et al. 2002), these related Sox proteins might compensate for the loss of Sox9. Conversely, normal development of oligodendrocyte progenitors in Sox10-deficient mice (Stolt et al. 2002) might be attributed to the presence of Sox9 and Sox8. In spinal cords lacking both Sox9 and Sox10, numbers of oligodendrocyte progenitors were more severely decreased (Fig. $5 \mathrm{~m}, \mathrm{n}$ ) than in spinal cords lacking only Sox9 (Fig. 5j,k,p). Most sections from Sox9/Sox10-deficient spinal cords, that were stained for $\beta$-galactosidase ${ }^{\text {Sox10 }}$, were devoid of oligodendrocyte progenitors at $12.5 \mathrm{dpc}$ (Fig. $5 \mathrm{~m}, \mathrm{p}$ ). At $14.5 \mathrm{dpc}$, oligodendrocyte progenitors were reduced to $10 \%$ of wild-type levels in Sox9/Sox10-deficient spinal cords (Fig. 5n,p) compared with $22 \%$ in the Sox9-deficient spinal cords. All residual oligodendrocyte progenitors expressed Sox8, the only remaining Sox9-related protein (Fig. 6g). Sox8 was furthermore strongly expressed in the ventral ventricular zone of Sox9/Sox10deficient spinal cords (Fig. 6h), whereas in control spinal cords it was restricted to oligodendroglial cells dispersed throughout the mantle zone in a manner similar to Sox10 (Fig. 6i). This up-regulation of Sox8 was not only observed in Sox9/Sox10-deficient spinal cords, but already in Sox9-deficient spinal cords (Fig. 6j). Sox8 is most likely responsible for the residual level of oligodendrogenesis in the absence of both Sox9 and Sox10. Final proof will have to await the generation of triple knockouts, which is not feasible with the presently available mouse mutants (Britsch et al. 2001; Sock et al. 2001; Akiyama et al. 2002).

\section{Motoneuron development in the Sox9-deficient spinal cord}

With Sox9 expression in the common motoneuron/oligodendrocyte precursors of the pMN domain, we next analyzed the consequences of Sox 9 ablation on motoneurons by immunohistochemistry with antibodies directed against the homeodomain transcription factor $\mathrm{Hb} 9$ and the LIM homeodomain transcription factors islet-1 and islet-2 (islet). Whereas the $\mathrm{Hb} 9$ antibody is specific to motoneurons, the islet antibody additionally labels interneurons of the dorsal spinal cord (Liem et al. 1997). The number of these D2 interneurons was highly similar between wild-type and Sox9-deficient spinal cords from $12.5 \mathrm{dpc}$ to $16.5 \mathrm{dpc}$ (region 1 in Fig. $7 \mathrm{a}, \mathrm{e}, \mathrm{k}_{\text {; }}$ data not shown).

Motoneuron numbers, on the other hand, exhibited a statistically significant $30 \%$ increase in the forelimb area of Sox9-deficient spinal cords at $12.5 \mathrm{dpc}$ as judged by immunohistochemistry with both islet and $\mathrm{Hb} 9$ antibodies (region 2 in Fig. 7a,b,e,f,k). Instead of 136 isletpositive motoneurons per section in the wild-type, we observed on average 178 motoneurons in the Sox9-deficient spinal cord. The surplus of 42 motoneurons almost exactly matched the average number of oligodendrocyte progenitors missing in the Sox9-deficient spinal cord. In addition to those motoneurons that had already arrived at their final location in the ventral horn of the spinal cord (Fig. $7 \mathrm{k}$, region 2), there were cells in a more medial position (Fig. 7k, region 3 ) that were also recognized by both islet and $\mathrm{Hb} 9$ antibodies (Fig. 7a,b,e,f) and found at the same dorsoventral position as the directly adjacent Olig2-positive cells (Fig. 7a,e). The number of these cells,

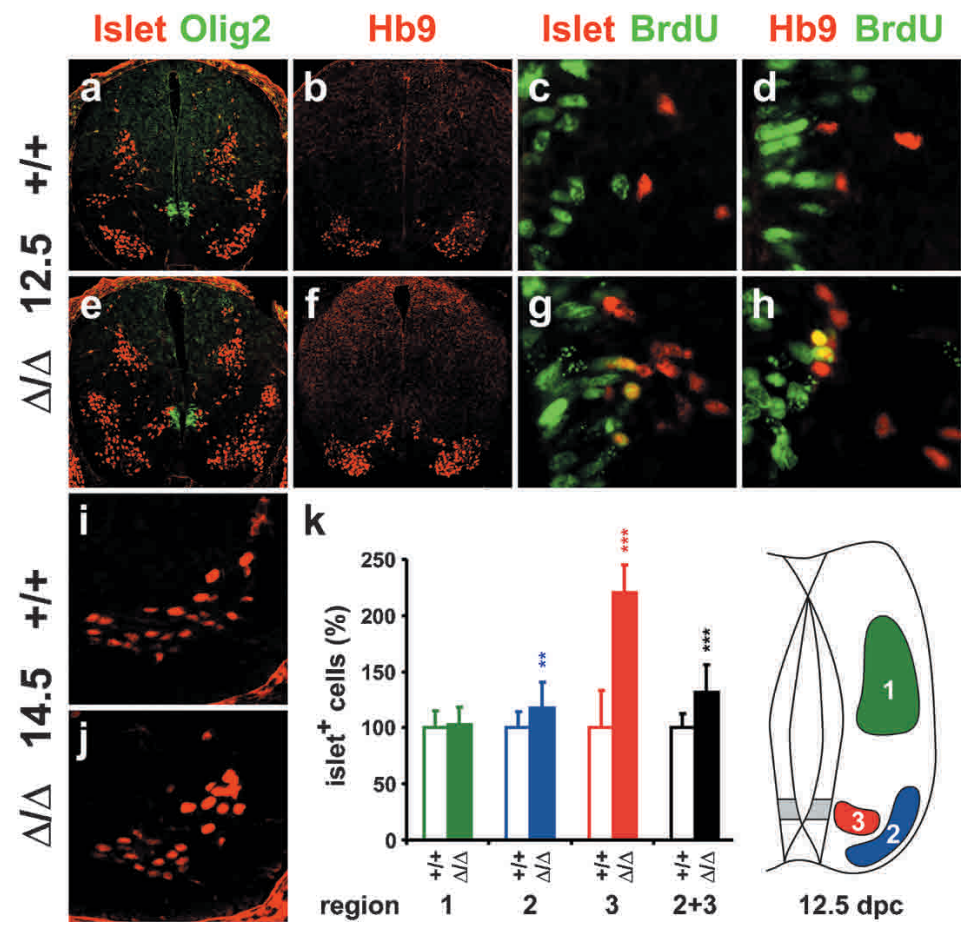

Figure 7. Motoneuron development in embryonic Sox9deficient spinal cords. Immunohistochemistry with antibodies directed against Islet-1/2 $(a, c, e, g, i, j)$ and $\mathrm{Hb} 9$ $(b, d, f, h$; both in red) were performed on transverse sections from the forelimb region of the embryos, alone $(b, f, i, j)$ or in combination with antibodies directed against Olig2 $(a, e)$ and $\mathrm{BrdU}(c, d, g, h ;$ both in green) at 12.5 dpc $(a-h)$ and $14.5 \mathrm{dpc}(i, j) .(a-d, i)$ Wild-type spinal cords. $(e-h, j) \operatorname{Sox}^{\Delta / \Delta}$ spinal cords. (k) Quantification of motoneurons in wild-type (open bars) and Sox9-deficient (filled bars) spinal cords. The number of Islet-positive cells at $12.5 \mathrm{dpc}$ was separately determined for the dorsal (region 1 , corresponding to D2 interneurons) and the ventral (region $2+3$, corresponding to motoneurons) spinal cord. Motoneurons were additionally subdivided according to their position (region 2, ventral horn; region 3, medial). At least 35 separate 10 - $\mu \mathrm{m}$ sections from the forelimb region of $\geq 2$ independent embryos were counted for each genotype. The number of cells obtained for the wild type was arbitrarily set to $100 \%$. All other values were expressed relative to wild-type levels and are presented as mean \pm S.E.M. Statistical significance was determined by the Student's t test and is indicated above the respective bars (two asterisks for $P \leq 0.01$, three asterisks for $P \leq 0.001$ ). 
Stolt et al.

which according to their marker gene expression are motoneurons, more than doubled in Sox9-deficient spinal cords, whereas ventral horn motoneurons were only increased by $15 \%$ relative to wild-type controls (Fig. $7 \mathrm{k}$ ). The position of these medial motoneurons in the proximity of the pMN domain indicates that they might have been generated late and were still in the process of migration. Following BrdU injection at $12.0 \mathrm{dpc}$, a fraction of these $\mathrm{Hb}$ //islet-positive cells closest to the pMN domain exhibited BrdU-labeled nuclei in Sox9-deficient spinal cords at $12.5 \mathrm{dpc}$, confirming their generation from actively proliferating cells during the last $12 \mathrm{~h}$ (Fig. $7 \mathrm{~g}, \mathrm{~h})$. In contrast, cells labeled simultaneously with BrdU and $\mathrm{Hb}$ / /islet were only very rarely observed in the wild type (Fig. 7c,d). Motoneuron increase in the Sox9deficient spinal cord is therefore likely caused by an unusually late production of extra motoneurons in the ventricular zone of the pMN domain. Considering the simultaneous reduction in oligodendrocyte progenitors and our failure to detect any significant changes in the rates of proliferation and apoptosis (data not shown), the most plausible explanation of these findings is a replacement of oligodendrocyte progenitors by surplus motoneurons.

After a period of trophic independence, motoneurons undergo programmed cell death to adjust their numbers to target tissue innervation. In the forelimb area of the wild-type spinal cord, motoneuron death peaks at 13.5 $\mathrm{dpc}$ and motoneuron numbers are appropriately trimmed soon after (Yamamoto and Henderson 1999). In agreement, we detected almost identical motoneuron numbers in the forelimb area of Sox9-deficient spinal cords and wild-type controls at $14.5 \mathrm{dpc}$ (Fig. $7 \mathrm{i}, \mathrm{j}$ ) or $16.5 \mathrm{dpc}$ (data not shown).

\section{Astrocyte development in the Sox9-deficient spinal cord}

Because of the strong astrocytic expression of Sox9, we also investigated astrocyte development in Sox9-deficient spinal cords. At $12.5 \mathrm{dpc}$, astrocytes were not yet present or detectable with any of the available markers (data not shown). Using antibodies against S100 $\beta$, astrocytes were first reliably found at $14.5 \mathrm{dpc}$ in the wildtype spinal cord (Fig. 8a). A significant fraction of these cells was localized in close proximity to the ventricular zone at the same dorsoventral position as V2 interneurons (Fig. 8a, inset) indicating in agreement with published observations (Zhou and Anderson 2002; Pringle et al. 2003) that at least some of these S100ß-positive cells were generated in the p2 domain. S100 $\beta$-positive cells increased strongly in number throughout the mantle zone at late stages of embryonic development (Fig. 8b; data not shown), but were always fewer than the number of Sox9-expressing cells. Only a minor fraction of S100ßpositive cells coexpressed oligodendrocytic markers as previously reported (Zhou and Anderson 2002). Most started to acquire astrocyte morphology during late embryogenesis (Fig. 8b, inset), corroborating that the majority of S100ß-positive cells were astrocytes. In sharp contrast to the wild type, virtually no $S 100 \beta$ expression was detected in spinal cords of embryos with a CNS-specific Sox9 deficiency (Fig. 8d,e). Even at $16.5 \mathrm{dpc}$, we only observed sporadic staining in a few isolated cells at an intensity equal to the unspecific signal in motoneurons (Fig. 8e).

In an independent approach, in situ hybridizations were performed with an antisense probe specific for Fgfr3 that labels both astrocytes and their (radial glia) progeni-

Figure 8. Astrocyte development in embryonic Sox9-deficient spinal cords. Immunohistochemistry with antibodies specific for the astrocyte marker $\operatorname{S100\beta }(a, b, d, e)$ and in situ hybridization with antisense probes specific for the astrocyte markers Glast $(c, f), \operatorname{Fgfr} 3(g, h, j, k)$, and glutamine synthase $(\mathrm{Gln} S ; i, 1)$ were performed on transverse sections from the forelimb region of embryos. ( $a-$ $c, g-i)$ Wild-type $(+/+)$ spinal cords. $(d-f, j-l)$ Sox $9^{\Delta / \Delta}$ spinal cords. $(a, d, g, i) 14.5$ dpc. $(b, c, e, f, h, i, k, l) 16.5$ dpc. (Insets) Costaining of $\mathrm{S} 100 \beta$ (red) with Chx10 (green; $a$ ) and S100ß-positive $(b)$ astrocytes at high magnification.

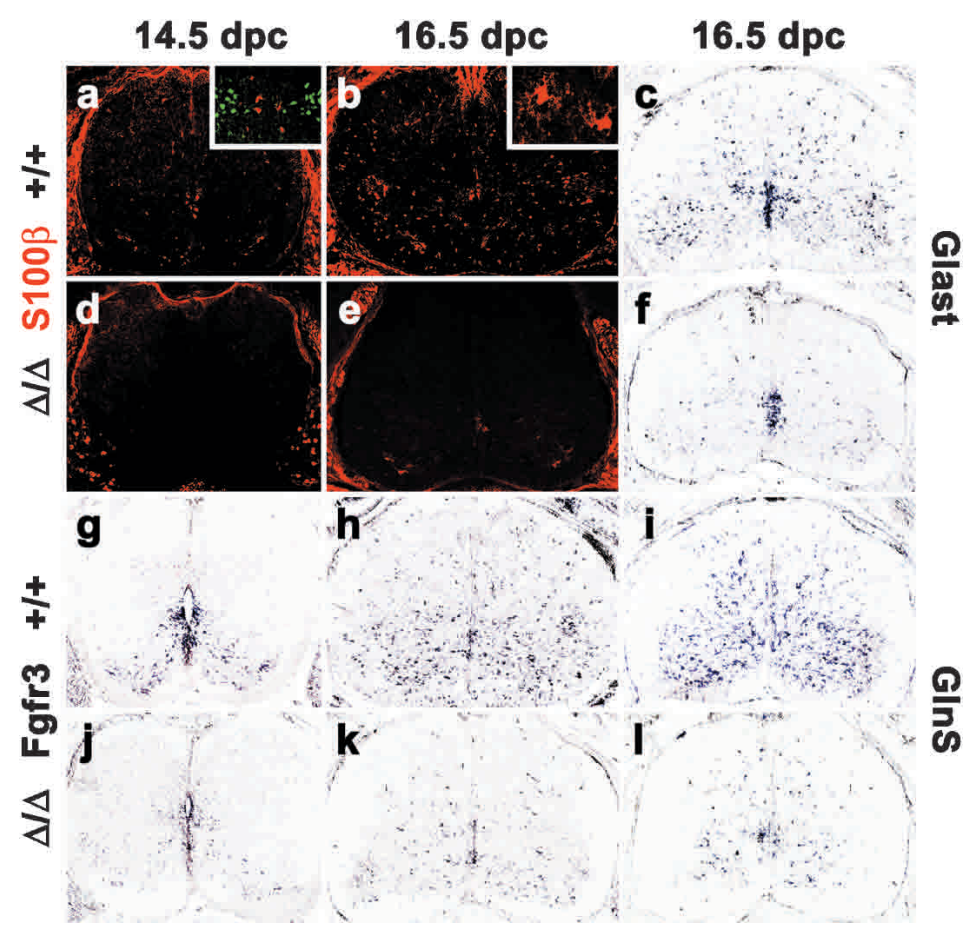


tors within the ventricular zone (Pringle et al. 2003). Accordingly, Fgfr3-positive cells were found both in the ventral part of the ventricular zone and in the surrounding parenchyma at $14.5 \mathrm{dpc}$ (Fig. 8g). Whereas the Fgfr3 signal in the ventricular zone of Sox9-deficient spinal cords was comparable to wild type, it was strongly reduced throughout the surrounding mantle zone (Fig. 8j). The difference in Fgfr3 expression levels was even more obvious at 16.5 dpc (Fig. 8h,k), with hardly any Fgfr3positive cell somata outside the ventricular zone in Sox9-deficient spinal cords.

Additional in situ hybridizations were carried out against the glial glutamate transporter Glast and glutamine synthase (GlnS) to confirm the astrocyte defect. Both of these markers are expressed in radial glia and in astrocytes, with the main site of expression shifting from radial glia to astrocytes as development proceeds (Malatesta et al. 2003; Pringle et al. 2003). At 16.5 dpc, astrocyte expression is dominant, with varying levels of residual expression in radial glia for both markers. We detected a significant decrease of expression for both Glast (Fig. 8c,f) and GlnS (Fig. 8i,1) in the Sox9-deficient spinal cord at $16.5 \mathrm{dpc}$. Although Glast expression was reduced to an extent comparable to Fgfr3 (Fig. 8, cf. c,f and h,k), the remaining GlnS expression in the Sox9-deficient spinal cord appeared slightly higher (Fig. 8i,1).

Whereas all of these markers labeled a strongly overlapping or even identical cell population in the developing spinal cord that likely corresponds to gray matter astrocytes, CD44 did not. CD44, which has been described to label a subpopulation of dorsal astrocytes (Liu et al. 2002), was expressed at comparable levels in wildtype and Sox9-deficient spinal cords (data not shown). GFAP immunoreactivity also appeared in a pattern different from other astrocytic markers, thus supporting a heterogeneous origin of astrocytes (Miller and Szigeti 1991). Expression of GFAP protein started only at 16.5 dpc, the latest time point of our analysis. The few GFAPexpressing cells visible at this age were restricted to the marginal zone and thus represent white matter astrocytes. The number and location of GFAP-positive cells were comparable in wild-type and Sox9-deficient spinal cords (data not shown), indicating that white matter astrocytes were not or not yet affected by Sox 9 ablation. This contrasts with the severe loss of gray matter astrocytes revealed by our study. This astrocyte defect became more pronounced as development proceeded and thus exhibited kinetics completely different from the oligodendrocyte defect. One contributing factor might be the later generation of astrocytes relative to oligodendrocyte precursors. When astrocytes appear in the spinal cord, Sox9 ablation is almost complete and therefore more effective than at the earlier time of oligodendrocyte generation. Additionally, we have shown that astrocytes do not express any class E Sox protein apart from Sox9, supporting the argument that Sox9 function might be nonredundant at all phases of astrocyte development. This is in stark contrast to the overlapping expression of Sox8, Sox9, and Sox10 during oligodendrocyte development.

\section{V2 interneuron development in the Sox9-deficient spinal cord}

As gray matter astrocytes are known to be at least partly derived from the $\mathrm{p} 2$ domain immediately dorsal to the pMN domain (Zhou and Anderson 2002; Pringle et al. 2003), we also analyzed V2 interneuron production in Sox9-deficient spinal cords using antibodies directed against the transcription factor Chx10. Similar to our observation on motoneuron numbers, we detected an increase in V2 interneurons in the absence of Sox9. At 12.5 dpc, there was a slight $12 \%$ increase in all Chx10-positive V2 interneurons (Fig. 9a,d,g). The surplus of V2 in-
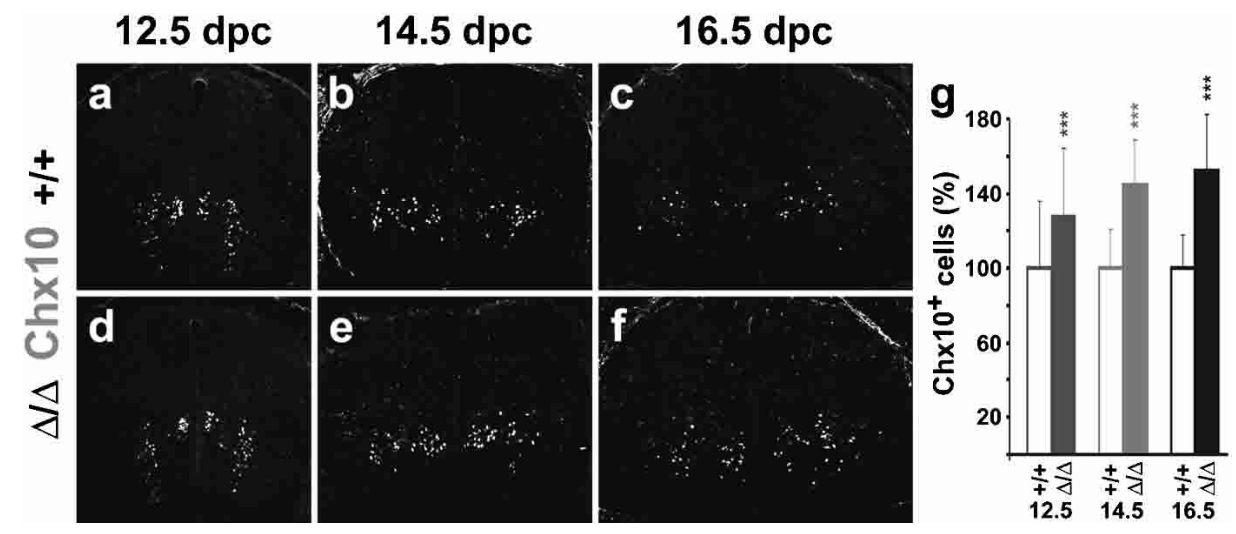

Figure 9. V2 interneuron development in embryonic Sox9-deficient spinal cords. Immunohistochemistry with antibodies directed against the V2 interneuron marker Chx10 were performed on transverse sections from the forelimb region of embryos. $(a-c)$ Wild-type spinal cords. $(d-f)$ Sox $9^{\Delta / \Delta}$ spinal cords. $(a, d) 12.5$ dpc. $(b, e) 14.5$ dpc. $(c, f) 16.5$ dpc. $(g)$ Quantification of Chx10-positive V2 interneurons in wild-type (open bars) and Sox9-deficient (filled bars) spinal cords. The number of Chx10-positive cells was quantified at 12.5, 14.5, and $16.5 \mathrm{dpc}$ as indicated below the bars. At least 35 separate $10-\mu \mathrm{m}$ sections from the forelimb region of $\geq 2$ independent embryos were counted for each genotype. The number of cells obtained for the wild type was arbitrarily set to $100 \%$. All other values were expressed relative to wild-type levels and are presented as mean \pm S.E.M. Statistical significance was determined by the Student's $t$ test and is indicated above the respective bars (three asterisks for $P \leq 0.001$ ). 
Stolt et al.

terneurons constantly increased throughout embryonic development, with $28 \%$ more neurons in the forelimb area of Sox9-deficient spinal cords at $14.5 \mathrm{dpc}$ (Fig. 9b,e,g), and $48 \%$ more Chx10-positive neurons at 16.5 dpc (Fig. 9c,f,g). Loss of gray matter astrocytes thus correlated with an increase in V2 interneurons. Absolute numbers of lost astrocytes and surplus V2 interneurons did not match as closely as those for oligodendrocytes and motoneurons. At $14.5 \mathrm{dpc}$, for instance, twice as many S100ß-positive cells were lost as surplus V2 interneurons were gained, possibly pointing to a second origin of S100ß-positive cells outside the p2 domain. V2 interneurons probably replace those gray matter astrocytes derived from the p2 domain, in a manner analogous to motoneurons replacing oligodendrocytes. The different kinetics of increased motoneuron and V2 interneuron production might reflect the later appearance of astrocytes relative to oligodendrocytes and the different timing of apoptosis in these two neuronal subtypes.

\section{Discussion}

We assume that Sox 9 has two functions in the mammalian nervous system. Early and dorsally, it might be involved in the generation of neural crest as shown in
Xenopus (Spokony et al. 2002). Later and mostly ventrally, it appears to be involved in gliogenesis. Our results indicate that Sox9 is important both for the generation of gray matter astrocytes from the ventral ventricular zone including the p2 domain and for the generation of oligodendrocytes from the pMN domain. Interestingly, expression of Sox9 in the ventricular zone precedes the onset of gliogenesis. Whether this is relevant for the gliogenic function of Sox 9 is unknown at present. However, similar expression patterns have previously been observed at other sites of Sox9 function. Although a key determinant in chondrogenesis, Sox9 is already expressed in mesodermal cells long before they acquire a chondrogenic fate (Bi et al. 1999; Akiyama et al. 2002). Likewise, Sox 9 expression in the bisexual gonad significantly precedes its later role in male sex determination (Kent et al. 1996).

An active role for Sox 9 in the generation of astrocytes and oligodendrocytes is supported by gene expression studies in Sox9-transfected Neuro2a cells. Ectopic expression of Sox9 in these cells caused concomitant induction of several glial marker genes (Fig. 10a). These included astrocyte markers such as Fgfr3, GFAP, and GlnS, but also proteolipid protein (PLP) and 2',3'-cyclic nucleotide $3^{\prime}$-phosphodiesterase (CNP) as oligodendrocyte markers, indicating that Sox9 by itself does not dis-

a
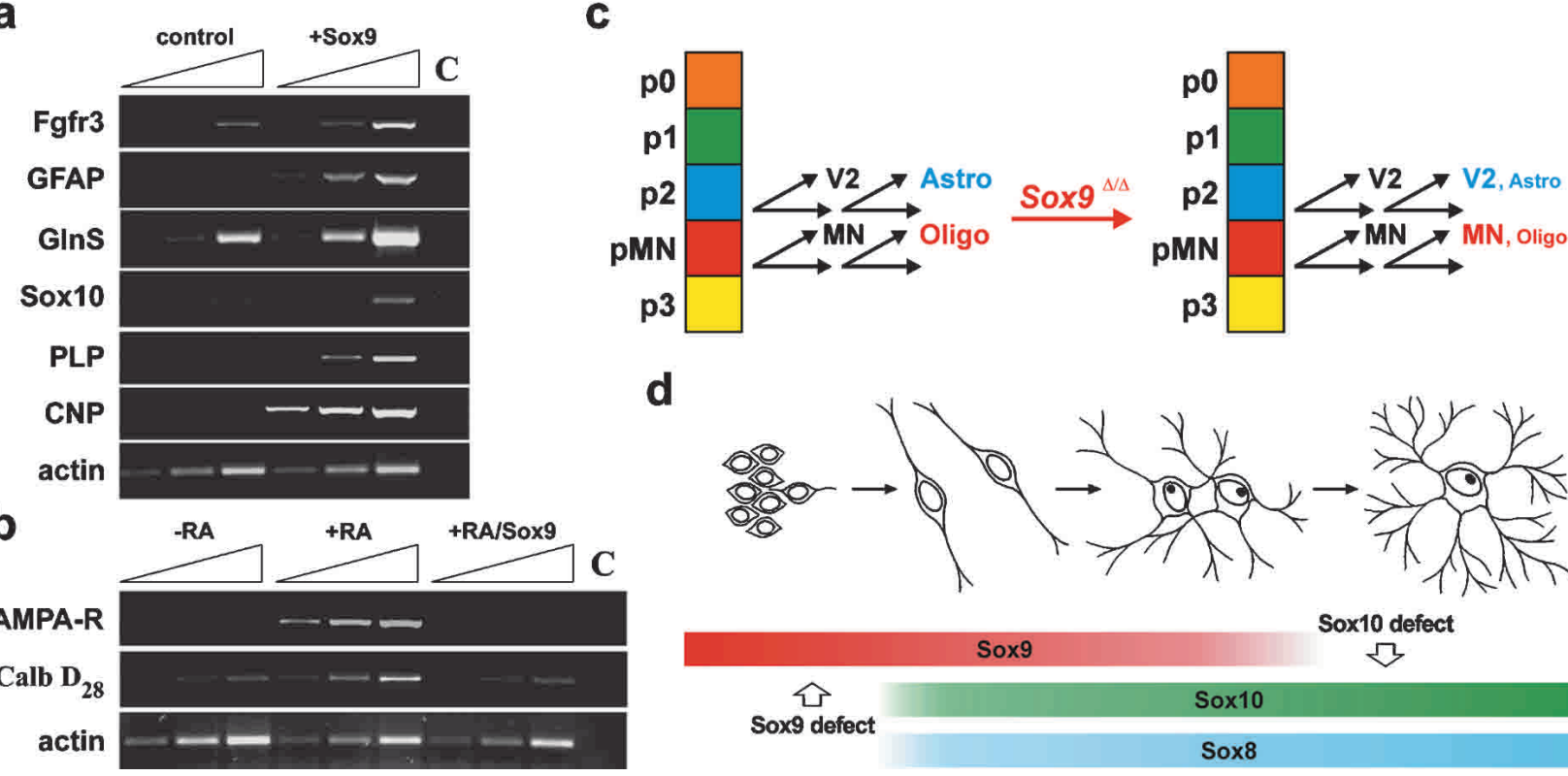

d
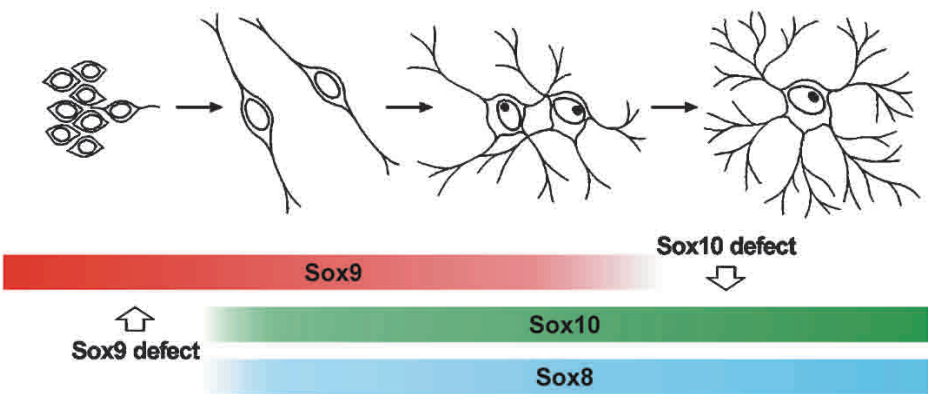

Figure 10. Mechanism of Sox9 function in oligodendrocytes. $(a, b)$ RT-PCR analyses on cDNA obtained from Neuro2A cells transiently transfected with $>90 \%$ efficiency with expression plasmids for GFP (control) or Sox9. Cells were kept under standard culture conditions $(a,-\mathrm{RA}$ in $b)$ or in retinoic-acid-containing medium to induce neuronal differentiation $(+\mathrm{RA}$ in $b)$. Transcript levels of glial markers (Fgfr3, GFAP, GlnS, Sox10, CNP, PLP in $a$ ), neuronal markers (AMPA receptor, calbindin $\mathrm{D}_{28}$ in $b$ ), and a housekeeping gene (actin) were compared semiquantitatively using increasing numbers of amplification cycles $(n, n+3, n+6)$. C, water control. $(c)$ Summary of Sox 9 function in the $\mathrm{p} 2$ and pMN domains of the embryonic spinal cord. Instead of switching from generation of neurons (V2 interneurons and motoneurons, respectively) to glia (astrocytes and oligodendrocytes, respectively), stem cells in both domains continue to primarily produce neurons of the correct subtype. (d) Summary of Sox gene expression in the oligodendrocyte lineage. Sox 9 expression precedes the expression of other class E Sox genes, but is no longer expressed in terminally differentiated oligodendrocytes in contrast to Sox10 and Sox8. This pattern of expression explains the observed oligodendrocyte defects in both Sox9- and Sox10deficient spinal cords. 
criminate between the two glial fates in this tissue culture system. We also observed induction of Sox10 upon ectopic expression of Sox9 in Neuro2a cells (Fig. 10a). It is unclear at present whether Sox10 expression is turned on directly by Sox 9 or is only indirectly increased as part of an oligodendrocyte-specific expression profile.

Upon treatment with retinoic acid, Neuro2a cells upregulate expression of several neuronal genes including the AMPA receptor and calbindin $\mathrm{D}_{28}$ (Fig. 10b). Induction of these neuronal genes was, however, completely suppressed when cells were transfected with Sox9 prior to treatment with retinoic acid. At least in tissue culture, Sox9 is thus capable of both actively inducing glial traits and simultaneously repressing neuronal traits.

Oligodendrogenesis in the pMN domain has previously been shown to be dependent on the expression of the transcription factor Olig2 (and to a lesser extent Olig1; Lu et al. 2002; Takebayashi et al. 2002; Zhou and Anderson 2002). Thus, it is tempting to speculate that it is the combination of Sox 9 and Olig2 that is essential for oligodendrocyte specification, with Sox 9 conferring glial identity and Olig2 conferring subtype identity (Fig. 10c). Isolated Olig2 expression is sufficient for motoneuron production, whereas additional Sox 9 expression would be required for oligodendrogenesis, suggesting that Sox9 expression in neuroepithelial cells of the pMN domain is involved in the neuron-glia switch. Ectopic expression of Olig2 has previously been shown to induce oligodendrocyte fate selectively in mesenchymally derived tissues of the chick embryo (Zhou et al. 2000). Endogenous Sox9 expression in this tissue (Wright et al. 1995) might be the reason.

Our model also predicts that Sox 9 still confers glial identity in the absence of Olig2. However, the chosen subtype would be a different one, which explains why neural stem cells of the p2 domain switch from V2 interneuron to astrocyte production following Sox 9 expression (Fig. 10c), and why the pMN domain in Olig1/2deficient mice gives rise to astrocytes rather than oligodendrocytes (Takebayashi et al. 2002; Zhou and Anderson 2002). Owing to the lack of probes, the inherent limitations of conditional gene ablation, and the current state of knowledge, we are presently unable to say whether Sox9 promotes gliogenesis in other domains of the ventricular zone.

Astrocytes are known to be neuroprotective and function as the major source of neurotrophic factors in the CNS. Additionally, astrocytes are involved in the formation of the blood-brain barrier and supply nutrients to neurons. A Sox9-dependent astrocyte defect could thus be a main cause for the generalized neuronal degeneration, hemorrhage, and breakdown of nervous tissue observed at the end of embryogenesis in the Sox9-deficient CNS. An involvement of oligodendrocytes appears less likely as their number had almost reached wild-type levels at the time of generalized neuronal degeneration. Furthermore, a primary, cell-autonomous defect in CNS blood vessels is ruled out, as Sox9 is not expressed in the endothelial cells lining these vessels. Note that we cannot completely exclude contributions from Sox9-depen- dent alterations outside the CNS that have gone unnoticed in our analysis.

Recovery of oligodendrocyte numbers during the course of embryonic development is most easily explained by functional redundancy between Sox 9 and the related Sox10 and Sox8 (Fig. 10d). With Sox9 preceding Sox 10 and Sox 8 expression, there is only a short window early during oligodendrocyte development in which Sox9 alone is expressed. It is thus not surprising that the Sox9-specific oligodendrocyte defect falls into this time window of early specification. Sox 9 expression in the oligodendrocyte lineage ends around the onset of terminal differentiation so that mature oligodendrocytes express only Sox10 and lower levels of Sox8 (Kuhlbrodt et al. 1998b; Sock et al. 2001). In agreement with this change in expression, the previously reported Sox10-specific defect in the oligodendrocyte lineage starts at the time of terminal differentiation (Stolt et al. 2002). The relatively low amounts of Sox 8 in these cells are probably insufficient to rescue the terminal differentiation defect. Thus, Sox9 has a unique role for the specification event in the oligodendrocyte lineage. In astrocytes, Sox9 is equally important for specification, but probably has additional functions as it continues to be expressed into adulthood in a manner nonoverlapping with either Sox8 or Sox10.

\section{Materials and methods}

\section{Animal husbandry and genotyping}

Mice with a $\operatorname{Sox} 9^{\text {loxP }}$ allele (Akiyama et al. 2002) were kept as homozygotes, or as heterozygotes in the presence of the nestin Cre transgene (Tronche et al. 1999) or additional Sox10 ${ }^{\text {lacZ }}$ (Stolt et al. 2002) and Sox $8^{\text {lacz }}$ (Sock et al. 2001) alleles. For the generation of CNS-specific Sox9-deficient mice, Sox9loxP/loxP females were bred to Sox $9^{+/ 10 x P}$ males that additionally carried the nestin Cre transgene. For the generation of CNS-specific double Sox9/Sox10-deficient mice, double heterozygotes were intercrossed. Inheritance of the nestin Cre was again through the male germ line. Genotyping was performed by PCR. Primers are available upon request.

\section{Antibody production}

Antibodies against Sox9 were generated in rabbit against a purified bacterially expressed protein consisting of amino acids 182-229 of mouse Sox9 fused to amino acids 305-438. Similarly, a purified bacterially expressed protein consisting of amino acids 181-233 and 308-400 of Sox10 was used for antibody production. Both antisera were affinity-purified. The Sox10 antibody had to be additionally preadsorbed on powder of Sox10-deficient embryos.

Immunohistochemistry, TUNEL assays, BrdU labeling, X-gal staining, and in situ hybridization

Embryos were obtained at 8.5-18.5 dpc from staged pregnancies. Paraformaldehyde-fixed, $10-\mu \mathrm{m}$ cryotome sections of genotyped, age-matched mouse embryos, neonatals, or adult mice were used for immunohistochemistry according to standard protocols. For better comparison, all shown embryonic spinal cord sections are from the forelimb level. Similar results were 
also obtained at other axial levels. The following primary antibodies were used in various combinations: anti-MBP mouse monoclonal (1:100 dilution; Roche Biochemicals), anti-GFAP mouse monoclonal (1:100 dilution; Roche Biochemicals), antiPCNA mouse monoclonal (1:100 dilution; Roche Biochemicals), anti-NeuN mouse monoclonal (1:500 dilution; Chemicon), anti-islet mouse monoclonal (1:2000 dilution; Developmental Studies Hybridoma Bank), anti-Hb9 mouse monoclonal (1:50 dilution; Developmental Studies Hybridoma Bank), antiNkx2.2 mouse monoclonal (1:50 dilution; Developmental Studies Hybridoma Bank), anti-SoxE mouse monoclonal (undiluted; Paratore et al. 2001), anti-PECAM-1 rat monoclonal (1:50 dilution; Pharmingen), anti-Flk-1 rat monoclonal (1:20 dilution; Pharmingen), anti-PDGF receptor $\alpha$ rat monoclonal (1:100 dilution; Pharmingen), anti-Chx10 rabbit antiserum (1:5000 dilution; gift of J. Briscoe, NIMR, London), anti-B-FABP rabbit antiserum (1:10.000 dilution; gift of C. Birchmeier and T. Müller, MDC, Berlin), anti-S100 $\beta$ rabbit antiserum (1:500 dilution; Dako), anti-Olig2 rabbit antiserum (1:2000 dilution; gift of $\mathrm{H}$. Takebayashi, Kyoto University), affinity-purified anti-NG2 rabbit antiserum (1:1000 dilution; gift of W. Stallcup, Burnham Institute, La Jolla), affinity-purified anti-Sox 9 rabbit antiserum (1:2000 dilution), affinity-purified anti-Sox10 antiserum (1:100 dilution), anti- $\beta$-galactosidase rabbit antiserum (1:500 dilution, ICN), or anti- $\beta$-galactosidase goat antiserum (1:500 dilution, Biotrend). Secondary antibodies conjugated to Cy2 and Cy3 immunofluorescent dyes (Dianova) were used for detection.

TUNEL assays were performed according to the manufacturer's protocol (Q-Biogene). For BrdU labeling, pregnant mice were injected with $100 \mu \mathrm{g}$ of BrdU per gram body weight $12 \mathrm{~h}$ before embryo preparation. Incorporated BrdU was detected on tissue sections using an Alexa-488-coupled mouse monoclonal antibody directed against BrdU (Molecular Probes) at a 1:20 dilution. $\mathrm{X}$-gal stainings followed standard procedures. In situ hybridizations were carried out on 20 - $\mu$ m-thick cryotome sections as described (Britsch et al. 2001) using DIG-labeled probes for Nkx6.1 (gift of M. Sander, ZMNH, Hamburg), GlnS, Fgfr3 (gift of W.D. Richardson, UCL, London), Glast, Olig2, and Irx3. Samples were analyzed and documented using either a Leica TCS SL confocal microscope or a Leica inverted microscope (DMIRB) equipped with a cooled MicroMax CCD camera (Princeton Instruments).

Tissue culture, transient transfections, and reverse transcriptase PCR (RT-PCR)

Neuro2A cells were kept in DMEM supplemented with 5\% fetal calf serum as described (Peirano et al. 2000) and transiently transfected with CMV-based expression vectors for GFP or Sox9 using Superfect (QIAGEN). Transfection efficiencies were $>90 \%$ as judged by GFP autofluorescence. Retinoic-acid-induced neuronal differentiation of Neuro2a cells and preparation of total RNA using Trizol Reagent (Invitrogen) followed standard procedures. Detection of products specific for Fgfr3, GFAP, GlnS, Sox10, CNP, PLP, AMPA receptor, calbindin $\mathrm{D}_{28}$, and actin in cDNA generated by reverse transcription of RNA from these cells was by semiquantitative PCR starting with 16 cycles for actin; with 21-24 cycles for Fgfr3, GFAP, GlnS, and PLP; and with 27-29 cycles for Sox10, CNP, AMPA receptor, and calbindin $\mathrm{D}_{28}$. Sequences of PCR primers and exact PCR cycling conditions are available upon request.

\section{Acknowledgments}

We thank J. Briscoe, C. Birchmeier, T. Müller, H. Takebayashi, and W. Stallcup for the gift of antibodies, W.D. Richardson and
M. Sander for in situ probes, and G. Schütz for the Nestin-Cre mice. This study was supported by grant We1326/7-2 from the DFG to M.W.

The publication costs of this article were defrayed in part by payment of page charges. This article must therefore be hereby marked "advertisement" in accordance with 18 USC section 1734 solely to indicate this fact.

\section{References}

Akiyama, H., Chaboissier, M.-C., Martin, J.F., Schedl, A., and de Crombrugghe, B. 2002. The transcription factor Sox 9 has essential roles in successive steps of the chondrocyte differentiation pathway and is required for expression of Sox 5 and Sox6. Genes \& Dev. 16: 2813-2828.

Bi, W., Deng, J.M., Zhang, Z., Behringer, R.R., and de Crombrugghe, B. 1999. Sox9 is required for cartilage formation. Nat. Genet. 22: 85-89.

Bi, W., Huang, W., Whitworth, D.J., Deng, J.M., Zhang, Z., Behringer, R.R., and de Crombrugghe, B. 2001. Haploinsufficiency of Sox 9 results in defective cartilage primordia and premature skeletal mineralization. Proc. Natl. Acad. Sci. 98: 6698-6703.

Bignami, A. and Dahl, D. 1974. Astrocyte-specific protein and radial glia in the cerebral cortex of newborn rat. Nature 252: 55-56.

Bowles, J., Schepers, G., and Koopman, P. 2000. Phylogeny of the SOX family of developmental transcription factors based on sequence and structural indicators. Dev. Biol. 227: 239255.

Britsch, S., Goerich, D.E., Riethmacher, D., Peirano, R.I., Rossner, M., Nave, K.A., Birchmeier, C., and Wegner, M. 2001. The transcription factor Sox10 is a key regulator of peripheral glial development. Genes \& Dev. 15: 66-78.

Foster, J.W., Dominguez-Steglich, M.A., Guioli, S., Kwok, C., Weller, P.A., Stevanovic, M., Weissenbach, J., Mansour, S., Young, I.D., Goodfellow, P.N., et al. 1994. Campomelic dysplasia and autosomal sex reversal caused by mutations in an SRY-related gene. Nature 372: 525-530.

Fu, H., Qi, Y., Tan, M., Cai, J., Takebayashi, H., Nakafuku, M., Richardson, W., and Qiu, M. 2002. Dual origin of spinal oligodendrocyte progenitors and evidence for the cooperative role of Olig2 and Nkx2.2 in the control of oligodendrocyte differentiation. Development 129: 681-693.

Herbarth, B., Pingault, V., Bondurand, N., Kuhlbrodt, K., Hermans-Borgmeyer, I., Puliti, A., Lemort, N., Goossens, M., and Wegner, M. 1998. Mutation of the Sry-related Sox10 gene in Dominant megacolon, a mouse model for human Hirschsprung disease. Proc. Nat1. Acad. Sci. 95: 5161-5165.

Jessell, T.M. 2000. Neuronal specification in the spinal cord: Inductive signals and transcriptional codes. Nat. Rev. Genet. 1: 20-29.

Kent, J., Wheatley, S.C., Andrews, J.E., Sinclair, A.H., and Koopman, P. 1996. A male-specific role for SOX9 in vertebrate sex determination. Development 122: 2813-2822.

Kessaris, N., Pringle, N., and Richardson, W.D. 2001. Ventral neurogenesis and the neuron-glial switch. Neuron 31: 677680.

Kuhlbrodt, K., Herbarth, B., Sock, E., Enderich, J., HermansBorgmeyer, I., and Wegner, M. 1998a. Cooperative function of POU proteins and Sox proteins in glial cells. J. Biol. Chem. 273: 16050-16057.

Kuhlbrodt, K., Herbarth, B., Sock, E., Hermans-Borgmeyer, I., and Wegner, M. 1998b. Sox10, a novel transcriptional modulator in glial cells. J. Neurosci. 18: 237-250. 
Liem, K.F., Tremml, G., and Jessell, T.M. 1997. A role for the roof plate and its resident TGFb-related proteins in neuronal patterning in the dorsal spinal cord. Cell 91: 127-138.

Liu, Y., Wu, Y., Lee, J.C., Xue, H., Pevny, L.H., Kaprielian, Z., and Rao, M.S. 2002. Oligodendrocyte and astrocyte development in rodents: An in situ and immunohistological analysis during embryonic development. Glia 40: 25-43.

Lu, Q.R., Sun, T., Zhu, Z., Ma, N., Garcia, M., Stiles, C.D., and Rowitch, D.H. 2002. Common developmental requirement for olig function indicates a motor neuron/oligodendrocyte connection. Cell 109: 75-86.

Malatesta, P., Hack, M.A., Hartfuss, E., Kettenmann, H., Klinkert, W., Kirchhoff, F., and Götz, M. 2003. Neuronal or glial progeny: Regional differences in radial glia fate. Neuron 37: 751-764.

Miller, R.H. and Szigeti, V. 1991. Clonal analysis of astrocyte diversity in neonatal rat spinal cord cultures. Development 113: 353-362.

Paratore, C., Goerich, D.E., Suter, U., Wegner, M., and Sommer, L. 2001. Cellular role of Sox10 in neural crest development. Development 128: 3949-3961.

Peirano, R.I., Goerich, D.E., Riethmacher, D., and Wegner, M. 2000. Protein zero expression is regulated by the glial transcription factor Sox10. Mol. Cell. Biol. 20: 3198-3209.

Pompolo, S. and Harley, V.R. 2001. Localisation of the SRYrelated HMG box protein, SOX9, in rodent brain. Brain Res. 906: $143-148$.

Pringle, N.P., Yu, W.-P., Howell, M., Colvin, J.S., Ornitz, D.M., and Richardson, W.D. 2003. Fgfr3 expression by astrocytes and their precursors: Evidence that astrocytes and oligodendrocytes originate in distinct neuroepithelial domains. Development 130: 93-102.

Sock, E., Schmidt, K., Hermanns-Borgmeyer, I., Bösl, M.R., and Wegner, M. 2001. Idiopathic weight reduction in mice deficient in the high-mobility-group transcription factor Sox8. Mol. Cell. Biol. 21: 6951-6959.

Southard-Smith, E.M., Kos, L., and Pavan, W.J. 1998. Sox10 mutation disrupts neural crest development in Dom Hirschsprung mouse model. Nat. Genet. 18: 60-64.

Spokony, R.F., Aoki, Y., Saint-Germain, N., Magner-Fink, E., and Saint-Jeannet, J.P. 2002. The transcription factor Sox9 is required for cranial neural crest development in Xenopus. Development 129: 421-432.

Stolt, C.C., Rehberg, S., Ader, M., Lommes, P., Riethmacher, D., Schachner, M., Bartsch, U., and Wegner, M. 2002. Terminal differentiation of myelin-forming oligodendrocytes depends on the transcription factor Sox10. Genes \& Dev. 16: 165170.

Takebayashi, H., Nabeshima, Y., Yoshida, S., Chisaka, O., and Ikenaka, K. 2002. The basic helix-loop-helix factor olig2 is essential for the development of motoneuron and oligodendrocyte lineages. Curr. Biol. 12: 1157-1163.

Tronche, F., Kellendonk, C., Kretz, O., Gass, P., Anlag, K., Orban, P.C., Bock, R., Klein, R., and Schütz, G. 1999. Disruption of the glucocorticoid receptor gene in the nervous system results in reduced anxiety. Nat. Genet. 23: 99-103.

Wagner, T., Wirth, J., Meyer, J., Zabel, B., Held, M., Zimmer, J., Pasantes, J., Bricarelli, F.D., Keutel, J., Hustert, E., et al. 1994. Autosomal sex reversal and campomelic dysplasia are caused by mutations in and around the SRY-related gene Sox9. Cell 79: 1111-1120.

Wegner, M. 1999. From head to toes: The multiple facets of Sox proteins. Nucleic Acids Res. 27: 1409-1420.

Wright, E., Hargrave, M.R., Christiansen, J., Cooper, L., Kun, J., Evans, T., Gangadharan, U., Greenfield, A., and Koopman, P. 1995. The Sry-related gene Sox9 is expressed during chon- drogenesis in mouse embryos. Nat. Genet. 9: 15-20.

Yamamoto, Y. and Henderson, C.E. 1999. Patterns of programmed cell death in populations of developing spinal motoneurons in chicken, mouse, and rat. Dev. Biol. 214: 60-71.

Zhou, Q. and Anderson, D.J. 2002. The bHLH transcription factors olig2 and olig1 couple neuronal and glial subtype specification. Cell 109: 61-73.

Zhou, Q., Wang, S., and Anderson, D.J. 2000. Identification of a novel family of oligodendrocyte lineage-specific basic helixloop-helix transcription factors. Neuron 25: 331-343.

Zhou, Q., Choi, G., and Anderson, D.J. 2001. The bHLH transcription factor Olig2 promotes oligodendrocyte differentiation in collaboration with Nkx2.2. Neuron 31: 791-807. 


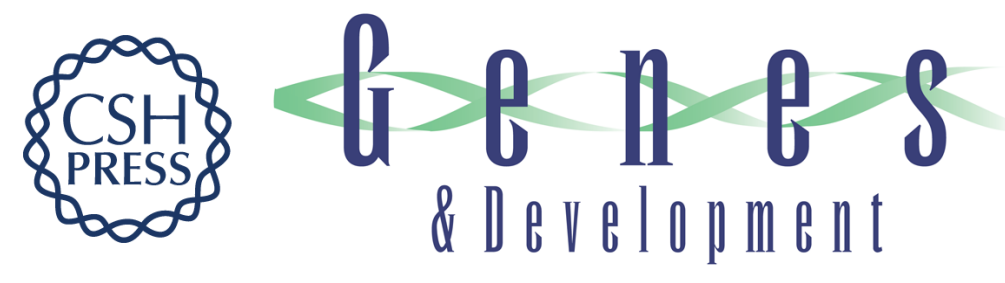

\section{The Sox9 transcription factor determines glial fate choice in the developing spinal cord}

C. Claus Stolt, Petra Lommes, Elisabeth Sock, et al.

Genes Dev. 2003, 17:

Access the most recent version at doi:10.1101/gad.259003

References This article cites 34 articles, 13 of which can be accessed free at: http://genesdev.cshlp.org/content/17/13/1677.full.html\#ref-list-1

License

Email Alerting

Receive free email alerts when new articles cite this article - sign up in the box at the top Service right corner of the article or click here.

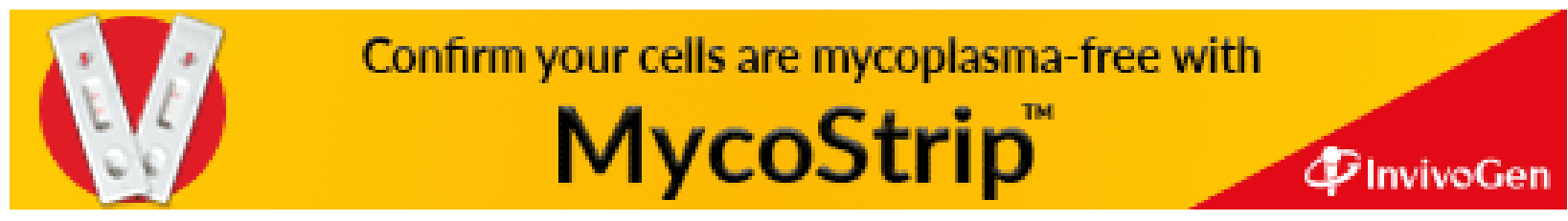

